Artikel Penelitian

\title{
Pengaruh Deep-Fat Frying terhadap Kandungan Asam Glutamat pada Bumbu Penyedap Granul Spirulina sp.
}

\section{Effect of Deep-Fat Frying to The Glutamic Acid Content in Spirulina sp. Granule Flavor Enhancer}

Bernadeta Pingkan Larasati, Victoria Kristina Ananingsih, Laksmi Hartayanie, Alberta Rika Pratiwi*

Program Studi Teknologi Pangan, Fakultas Teknologi Pertanian, Universitas Katolik Soegijapranata, Semarang

*Korespondensi dengan penulis (pratiwi@unika.ac.id)

Artikel ini dikirim pada tanggal 3 Oktober 2018 dan dinyatakan diterima tanggal 26 Mei 2019. Artikel ini juga dipublikasi secara online melalui

https://ejournal2.undip.ac.id/index.php/jatp. Hak cipta dilindungi undang-undang. Dilarang diperbanyak untuk tujuan komersial.

Diproduksi oleh Indonesian Food Technologists® @2019

\begin{abstract}
Abstrak
Penelitian ini bertujuan mengetahui pengaruh deep-fat frying terhadap kandungan asam glutamat bumbu penyedap granul Spirulina sp. yang telah diaplikasikan ke dalam adonan tepung terigu. Penelitian pendahuluan dilakukan untuk menghasilkan tiga formulasi bumbu penyedap granul Spirulina $s p$ berdasarkan kadar gula dan kadar garam bumbu 3 produk komersial. Tiga formulasi penyedap granul Spirulina $s p$ diaplikasikan ke dalam tepung terigu yang kemudian digoreng dengan metode deep-fat frying pada suhu 140,160 , dan $180^{\circ} \mathrm{C}$ hingga matang. Adonan sebelum dan sesudah penggorengan dianalisis warnanya menggunakan chromameter. Kandungan asam glutamat adonan setelah penggorengan kemudian dianalisis menggunakan L-glutamate assay kit dan diuji spektrofotometer pada panjang gelombang $492 \mathrm{~nm}$. Hasil penelitian menunjukkan bahwa proses penggorengan menyebabkan perubahan warna pada adonan. Peningkatan suhu penggorengan dari 140 ke $180^{\circ} \mathrm{C}$ menyebabkan penurunan nilai $L^{*}$ dari $\pm 47 \mathrm{ke} \pm 39$, penurunan nilai $b^{*}$ dari $\pm 26 \mathrm{ke} \pm 19$, serta peningkatan nilai $a^{*}$ dari $\pm 8 \mathrm{ke} \pm 10$. Hasil penelitian juga menunjukkan peningkatan suhu penggorengan $140 \mathrm{ke} 180^{\circ} \mathrm{C}$ yang menyebabkan penurunan kandungan asam glutamat adonan bumbu penyedap granul Spirulina sp. dari \pm 8 menjadi $\pm 3 \mathrm{mg} / 100 \mathrm{~g}$. Kesimpulannya, peningkatan suhu penggorengan menyebabkan perubahan warna dan penurunan kandungan asam glutamat pada semua formulasi bumbu penyedap yang diimplentasikan pada adonan tepung terigu.
\end{abstract}

Kata kunci: Spirulina sp., bumbu penyedap granul, asam glutamat, deep-fat frying.

\begin{abstract}
This research aims to determine the effect of deep-fat frying on the content of glutamic acid in Spirulina sp. granule flavor enhancer that has been applied to the flour dough. Preliminary research was produced three formulas of Spirulina sp. granule flavor enhancer, that were formulated based on sugar and salt content on three commercial seasoning brands. Thus, three formulas were applied to wheat flour then fried with deep-fat frying method at 140,160, and $180^{\circ} \mathrm{C}$ until cooked well. The color of doughs before and after frying were analyzed using chromameter. The glutamic acid content were analyzed using L-glutamate assay kit and tested by spectrophotometer at $492 \mathrm{~nm}$. As results, frying process changed the color of the dough. The increase in the frying temperature from 140 to $180^{\circ} \mathrm{C}$ caused a decrease in value of $L$ from \pm 47 to \pm 39 , value of $b^{*}$ from \pm 26 to \pm 19 , and increase the value of $a^{*}$ from \pm 8 to \pm 10 . The increase in the temperature of frying from 140 to $180^{\circ} \mathrm{C}$ caused a decrease in glutamic acid content of Spirulina sp. from \pm 8 to $\pm 3 \mathrm{mg} / 100 \mathrm{~g}$. As conclusion, increase in the frying temperature might cause a change in color and decreased content of glutamic acid in the doughs.
\end{abstract}

Keywords: Spirulina sp., granules flavor enhancer, glutamic acid, deep-fat frying.

\section{Pendahuluan}

Bumbu penyedap rasa merupakan salah satu bahan tambahan pangan yang sering digunakan untuk memberikan rasa umami pada makanan sehingga sering ditambahkan ke dalam makanan untuk meningkatkan aroma dan rasa yang dapat mengintensifkan komponen rasa di dalam mulut saat makanan dikonsumsi (Banies and Brown, 2016). Adanya tujuan untuk memperoleh rasa yang terbaik, kemudian digunakan sebagai pertimbangan untuk mengembangkan penelitian tentang bahan pangan alami yang berfungsi sebagai bumbu penyedap rasa. Asam glutamat merupakan salah satu senyawa yang dapat menimbulkan rasa umami (Kurihara, 2015), yang terdapat secara alami pada berbagai jenis pangan (Jinap and Hajeb, 2010), antara lain pada produk daging, kaldu, buah-buahan, dan sayuran.
Spirulina sp. merupakan salah satu mikroalga yang memiliki kandungan asam glutamat yang tinggi, yaitu sebesar 7,3 sampai 9,5 g/100 g (Habib et al., 2008) sehingga berpotensi sebagai sumber penyedap rasa. Bumbu penyedap berbahan granul Spirulina sp. lazim dibuat dengan menggunakan metode foam mat drying yang prinsipnya adalah mengubah produk yang berbentuk cair menjadi busa yang kemudian diratakan menjadi lembaran tipis dan dikeringkan menggunakan udara panas untuk mencapai kadar air yang diinginkan (Sangamithra et al., 2014). Keuntungan dari metode foam-mat drying ini adalah dapat mengeringkan dengan cepat pada suhu yang lebih rendah, serta dapat menjaga kandungan nutrisi dalam bahan seperti asamasam amino (Sangamithra et al., 2014). Penambahan maltodekstrin DE 10 sebagai agen enkapsulan untuk meminimalkan kerusakan asam glutamat yang peka 
terhadap pengaruh panas (Hartiati and Mulyani, 2015), selain itu menurut Sansone et al. (2011), proses enkapsulasi pada dinding polimer memberikan perlindungan terhadap oksigen dan mencegah terjadinya degradasi kimia maupun enzimatik.

Menurut Ninomiya (2015), bumbu penyedap rasa dapat ditambahkan ke dalam berbagai jenis makanan dengan jenis pengolahan yang berbeda-beda yakni perebusan, pemanggangan, pengukusan, dan penggorengan. Penggorengan dengan metode deep-fat frying. menggunakan suhu berkisar $150-180^{\circ} \mathrm{C}$ (Fellows, 2009) yang dapat menyebabkan perubahan secara termofisika pada makanan seperti gelatinisasi pati dan denaturasi protein (Mallikarjunan et al., 2010). Selain itu, menurut Ngadi et al., (2008) terjadi perubahan secara mikrostruktural seperti timbulnya reaksi Maillard yang dapat menghancurkan asam amino.

Penelitian ini bertujuan untuk mengaplikasikan bumbu penyedap rasa granul Spirulina sp. ke dalam adonan tepung terigu yang kemudian diolah menggunakan proses deep-fat frying dengan berbagai variasi suhu. Aplikasi bumbu penyedap granul Spirulina sp. ke dalam adonan tepung terigu bermanfaat untuk mengetahui pengaruh proses pengolahan terkait dengan kandungan asam glutamatnya. Hasil penelitian ini diharapkan dapat digunakan sebagai dasar untuk membuat takaran atau ukuran apabila diimplemantasikan sebagai penyedap rasa dalam produk olahan makanan tertentu terutama produk dengan olahan berbasis tepung seperti produk gorengan.

\section{Materi dan Metode \\ Materi}

Bahan yang digunakan dalam penelitian ini berupa biomassa Spirulina sp. kering komersial, garam, gula, lada, maltodekstrin DE 10, anti caking Zeofree 5162 (Huber Engineered Materials), minyak goreng, tepung terigu, aquadest, $\mathrm{K}_{4}\left[\mathrm{Fe}(\mathrm{CN})_{6}\right] \cdot 3 \mathrm{H}_{2} \mathrm{O}$ (Merck, Germany), $\mathrm{ZnSO}_{4}$ (Merck, Germany), $\mathrm{NaOH}$ (Merck, Germany), L-glutamic acid assay kit (Megazyme, Ireland) yang terdiri dari larutan buffer $\mathrm{pH} 8,6$, Nicotinamide adenine dinucleotide $\left(\mathrm{NAD}^{+}\right)$dan lodonitrotetrazolium chloride (INT), diaphorase suspension, dan larutan glutamat dehidrogenase. Peralatan yang digunakan dalam penelitian ini berupa refrigerated sentrifuge (Hettich Zentrifugen D-78532 Type 2002, Germany), mixer, cabinet dryer, ayakan 9 mesh \& 36 mesh, oven, kertas saring (Whatman No. 1, China), hot plate, refractometer salinity (Atago S/Mill, Japan), digital brix refractometer (Hanna Instruments, Romania), spektrofotometer UV-VIS 1280 (Shimadzu, Japan), cuvette, Chromameter CR-400 (Minolta, Japan), vortex, micro pipet, termometer, deep fat fryer.

\section{Metode}

Penelitian ini dilaksanakan pada September 2017 hingga Mei 2018 yang bertempat di Laboratorium Rekayasa Pangan, Laboratorium Ilmu Pangan, dan Laboratorium Nutrisi dan Kuliner, Fakultas Teknologi
Pertanian

Universitas

Katolik

Soegijapranata,

Semarang.

Penentuan Formulasi Bumbu

Formulasi bumbu penyedap rasa berbahan Spirulina sp. granul ini terdiri komponen dari Spirulina sp., garam, gula dan lada. Dipilih 3 formula berdasar kandungan gula dan garam setara dengan tiga merek produk komersial terpilih yang beredar di pasaran yaitu merek Masako, Royco, dan Maggi. Penyesuaian kadar gula dan kadar garam ini dilakukan agar rasa yang ditimbulkan hampir menyerupai rasa dari bumbu komersial acuan. Kadar gula dan kadar garam diukur menggunakan digital brix refractometer dan refractometer salinity sebanyak 10 kali pengulangan tiap merek bumbu penyedap komersial.

\section{Pembuatan Bumbu Penyedap Granul Spirulina sp.}

Tahap pertama dilakukan pemecahan dinding sel Spirulina sp. dengan menggunakan metode reflux (Dewi et al., 2016). Biomassa Spirulina sp. kering sebanyak 40 gram dilarutkan dalam air sebanyak 1000 $\mathrm{ml}$, kemudian dilakukan pemanasan pada suhu $90^{\circ} \mathrm{C}$ selama 15 menit. Larutan lalu disaring menggunakan kain saring, lalu filtrat dipanaskan kembali dengan suhu $90^{\circ} \mathrm{C}$ selama 15 menit, kemudian disaring menggunakan 2 kain saring. Setelah itu filtrat dipanaskan kembali suhu $90^{\circ} \mathrm{C}$ selama 15 menit dan disentrifugasi dengan kecepatan 5000 rpm selama 10 menit. Supernatan dipisahkan dari endapannya lalu disaring dengan kertas saring menggunakan vacuum filter. Filtrat yang dihasilkan sebanyak $\pm 120 \mathrm{ml}$ yang digunakan untuk tahap pembuatan bumbu dengan filtrat sebanyak $\pm 30 \mathrm{ml}$ untuk satu formula bumbu.

Granulasi dilakukan bertahap yakni tahap pertama dilakukan terhadap filtrat Spirulina sp. Tahap berikutnya granulasi dilakukan terhadap komponen lainnya yakni garam, gula, serta lada. Supernatan hasil pemecahan dinding sel Spirulina sp., dicampur dengan komponen lainnya sesuai dengan formulasi yang ditentukan dan ditambahkan maltodekstrin DE 10. Teknologi granulasi menggunakan metode foam-mat drying (Sangamithra et al., 2014). Pertama-tama, filtrat Spirulina sp. dikocok dengan mixer hingga terbentuk busa (Bag et al., 2011). Busa dikeringkan dengan cabinet dryer pada suhu $60^{\circ} \mathrm{C}$ selama 8 jam. Selanjutnya dilakukan pengayakan bertingkat dengan ayakan 9 mesh dan 32 mesh sehingga didapat granula dengan ukuran yang berkisar 0,5 sampai $2 \mathrm{~mm}$ (Kuo and Acharya, 2012).

\section{Analisa Kandungan Asam Glutamat}

Sebanyak 10 gram bumbu dilarutkan dalam 100 $\mathrm{ml}$ akuades. Kemudian larutan disaring menggunakan kertas saring, lalu filtrat diambil sebanyak $0,1 \mathrm{ml}$ yang kemudian dimasukkan ke dalam cuvette yang kemudian ditambah $2 \mathrm{ml}$ akuades, 0,5 ml buffer $\mathrm{pH} 8,6$, $0,2 \mathrm{ml} \mathrm{NAD}{ }^{+}$dan INT, 0,05 ml diaphorase suspension. Setelah itu absorbansi diukur menggunakan spektrofotometer dengan panjang gelombang $492 \mathrm{~nm}$. Setelah itu ditambahkan 0,05 ml larutan glutamate 
dehydrogenase ke dalam cuvette, lalu diukur absorbansinya setelah 8 sampai 10 menit. Untuk mengetahui konsentrasi asam L-glutamat (g/l) dilakukan dengan perhitungan perkalian volume akhir (ml) dan berat molekul asam L-glutamat $(\mathrm{g} / \mathrm{mol})$ lalu dibagi dengan koefisien INT-formazan pada $492 \mathrm{~nm}$ (yaitu $19900 \mathrm{~mol}^{-1} \times \mathrm{cm}^{-1}$ ), dan volume sampel (ml). Setelah diketahui konsentrasi dari asam L-glutamat, maka dapat dihitung kadar asam L-glutamat $(\mathrm{g} / 100 \mathrm{~g})$ dalam bumbu dengan membagi konsentrasi asam Lglutamat dengan $\mathrm{w}_{\text {bumbu }}(10 \mathrm{~g} / 0,1 \mathrm{l})$. Hal ini dilakukan pada masing-masing jenis bumbu.

\section{Aplikasi Bumbu Penyedap Granul Spirulina sp}

Perbandingan tepung terigu dengan bumbu yang digunakan adalah 10 gram bumbu dalam 100 gram tepung terigu. Bumbu yang digunakan terdiri dari 3 macam formula granula Spirulina sp. dan granula garam enkapsulasi yang disesuaikan dengan kadar gula dan kadar garam dari produk komersial, yaitu Masako, Royco, dan Maggi, yang masing-masing disebut sebagai bumbu 1, bumbu 2, dan bumbu 3 . Kadar gula dan kadar garam masing-masing pada bumbu 1 sebesar 1,21\% dan 1,05\%, bumbu 2 sebesar $1,04 \%$ dan $0,90 \%$, serta bumbu 3 sebesar $1,06 \%$ dan $0,95 \%$.

Tepung terigu yang digunakan memiliki kadar protein $10 \%$. Setelah itu dicampur dengan $50 \mathrm{ml}$ air dan diaduk hingga kalis. Setelah kalis, adonan ditakar seberat 17 gram dipipihkan dengan ketebalan 0,65 mm dan diameter $4,53 \mathrm{~mm}$, kemudian digoreng menggunakan metode deep-fat frying dengan suhu 140, 160 , dan $180^{\circ} \mathrm{C}$ sampai matang. Adonan pada setiap perlakuan suhu terdiri dari 3 adonan pengulangan. Setelah itu dilakukan analisa warna dan pengecekan terhadap kandungan asam glutamat adonan hasil penggorengan.

\section{Analisis Warna terhadap Adonan}

Analisa warna dilakukan berdasarkan metode Winarno (2008) dengan menggunakan Chromameter pada adonan setelah dilakukan proses penggorengan. Chromameter dikalibrasi terlebih dahulu pada plat putih sebanyak tiga kali, kemudian adonan setelah penggorengan diletakkan pada tempat pengukuran sampel dan ditekan tombol. Nilai $L, a^{*}$, dan $b^{\star}$ yang tampak pada layar. Data dicatat dan pengamatan diulang sebanyak 3 kali di tempat berbeda kemudian dirata-rata hasilnya.

\section{Analisis Pendugaan Kandungan Asam Glutamat \\ Pendugaan kandungan asam glutamat dilakukan juga pada adonan sebelum dan sesudah penggorengan. Sebanyak 10 gram adonan dihaluskan dan dilarutkan dengan $100 \mathrm{ml}$ akuades. Kemudian disaring dengan kertas saring, setelah itu filtrat diambil $20 \mathrm{ml}$ dan dimasukkan ke dalam labu takar $100 \mathrm{ml}$. Proses pretreatment dilakukan terlebih dahulu dengan penambahan $60 \mathrm{ml}$ akuades, $5 \mathrm{ml}$ larutan reagen I, $5 \mathrm{ml}$ larutan reagen II, dan $10 \mathrm{ml} \mathrm{NaOH} 100 \mathrm{mM}$. Larutan reagen I adalah larutan 3,6 gram $\mathrm{K}_{4}\left[\mathrm{Fe}(\mathrm{CN})_{6}\right] \cdot 3 \mathrm{H}_{2} \mathrm{O}$}

yang dilarutkan dalam $100 \mathrm{ml}$ aquadest, sedangkan larutan reagen II adalah larutan 7,2 gram $\mathrm{ZnSO}_{4}$ yang dilarutkan dalam $100 \mathrm{ml}$ aquadest, serta $\mathrm{NaOH} 100 \mathrm{mM}$ didapat dari 4 gram $\mathrm{NaOH}$ yang dilarutkan dalam 1 I akuades. Larutan tersebut berfungsi untuk menghilangkan protein, serta lemak yang terdapat pada adonan setelah penggorengan. Selanjutnya larutan dicampur dan disaring dengan kertas saring Whatman No. 1. Lalu filtrat diambil $0,1 \mathrm{ml}$ dan diaplikasikan pada L-glutamic acid assay kit.

\section{Analisis Data}

Data yang diperoleh meliputi kandungan asam glutamat pada adonan setelah penggorengan dan analisa warna adonan setelah penggorengan diuji normalitasnya dengan menggunakan uji Shapiro-Wilk. Apabila sebaran datanya normal dianalisis dengan uji ANOVA dua arah pada tingkat kepercayaan 95\% $(\mathrm{P}<0,05)$ untuk mengetahui pengaruh suhu deep-fat frying dan jenis bumbu terhadap kandungan asam glutamat dan warna adonan. Setelah itu dilanjutkan dengan uji Wilayah Ganda Duncan.

\section{Hasil dan Pembahasan}

Kandungan Asam Glutamat Bumbu

Hasil analisa pendugaan kandungan asam glutamat pada bumbu penyedap granul Spirulina sp. menunjukkan bahwa kandungan asam glutamat pada bumbu 2 lebih besar dibandingkan dengan bumbu lain (Tabel 1). Hal ini berbanding lurus dengan jumlah komposisi granula Spirulina sp. pada bumbu.

\section{Analisa Warna Adonan setelah Penggorengan}

Hasil analisa warna pada adonan setelah penggorengan meliputi nilai $L^{*}$, nilai $a^{*}$, dan nilai $b^{*}$. Nilai $L^{*}$ menunjukkan spektrum cerah-gelap dengan rentang 0 (gelap) hingga 100 (putih). Nilai $L^{\star}$ adonan sebelum penggorengan pada adonan bumbu 1 , bumbu 2 , dan bumbu 3 secara berturut-turut yaitu 87,91 ; 87,32; dan 90,04 . Hasil nilai $L^{*}$ adonan setelah penggorengan menunjukkan bahwa semakin tinggi suhu penggorengan, maka semakin rendah nilai $L^{\star}$ (Tabel 2). $\mathrm{Hal}$ ini menunjukkan bahwa adonan hasil penggorengan cenderung menjadi gelap seiring dengan kenaikan suhu penggorengan. Hal ini sesuai dengan penelitian Echavarria et al. (2016) bahwa semakin tinggi suhu pemanasan menyebabkan sampel berubah menjadi lebih gelap. Berdasarkan uji Wilayah Ganda Duncan terdapat beda nyata $(P<0,05)$ pada nilai $L^{*}$ antar suhu penggorengan, namun tidak berbeda nyata antar jenis bumbu.

Nilai a* menunjukkan spektrum warna hijaumerah dengan rentang -60 (hijau) hingga +60 (merah). Nilai $a^{*}$ adonan sebelum penggorengan pada adonan bumbu 1, bumbu 2, dan bumbu 3 secara berturut-turut yaitu -2,59; $-2,57$; dan $-2,48$. Hasil nilai a* adonan setelah penggorengan (Tabel 3) menunjukkan bahwa semakin tinggi suhu penggorengan, maka semakin tinggi nilai a. Berdasarkan uji Wilayah Ganda Duncan terdapat beda nyata $(P<0,05)$ nilai $a^{*}$ antar suhu penggorengan, namun tidak beda nyata antar adonan 
jenis bumbu. Hal ini menunjukkan bahwa adonan hasil penggorengan cenderung semakin merah kecoklatan seiring dengan kenaikan suhu penggorengan.

Nilai $b^{*}$ menunjukkan spektrum warna biru-kuning dengan rentang -60 (biru) hingga +60 (kuning). Nilai b adonan sebelum penggorengan pada adonan bumbu 1 , bumbu 2, dan bumbu 3 secara berturut-turut yaitu 20,86; 20,54; dan 19,43. Hasil nilai b adonan setelah penggorengan menunjukkan bahwa adonan hasil penggorengan pada suhu 140 dan $160^{\circ} \mathrm{C}$ menjadi lebih kuning kecoklatan, sedangkan pada suhu $180^{\circ} \mathrm{C}$ adonan menjadi lebih coklat (Tabel 4). Berdasarkan uji Wilayah Ganda Duncan terdapat beda nyata $(P<0,05)$ pada nilai $b^{*}$ antar suhu penggorengan, namun tidak beda nyata antar adonan jenis bumbu. Hal ini juga sesuai dengan penelitian Echavarria et al. (2016) yang menyatakan bahwa bila glukosa dan asam glutamat dipanaskan akan menyebabkan perubahan warna menjadi kuning kecoklatan dan menjadi lebih coklat pada perlakuan suhu yang lebih tinggi.

Tabel 1. Kandungan asam glutamat $(\mathrm{mg} / 100 \mathrm{~g})$ tiga formulasi bumbu penyedap granul Spirulina sp.

\begin{tabular}{lc}
\hline Jenis Formulasi & Konsentrasi asam glutamat \\
Bumbu & \\
\hline Bumbu 1 & 10,827 \\
Bumbu 2 & 20,497 \\
Bumbu 3 & 11,256 \\
\hline
\end{tabular}

Tabel 2. Nilai $L^{\star}$ adonan dengan bumbu berbeda pada suhu penggorengan yang berbeda

\begin{tabular}{lcccc}
\hline \multirow{2}{*}{ Adonan } & \multicolumn{4}{c}{ Suhu Penggorengan $\left({ }^{\circ} \mathrm{C}\right)$} \\
\cline { 2 - 5 } & 30 & 140 & 160 & 180 \\
\hline Bumbu 1 & 87,91 & $47,74 \pm 1,56^{\mathrm{a}}$ & $42,76 \pm 2,22^{\mathrm{b}}$ & $39,72 \pm 2,04^{\mathrm{c}}$ \\
Bumbu 2 & 87,32 & $47,99 \pm 1,83^{\mathrm{a}}$ & $41,44 \pm 2,10^{\mathrm{b}}$ & $39,48 \pm 1,29^{\mathrm{c}}$ \\
Bumbu 3 & 90,04 & $47,53 \pm 1,25^{\mathrm{a}}$ & $43,58 \pm 0,87^{\mathrm{b}}$ & $41,73 \pm 1,18^{\mathrm{c}}$ \\
\hline
\end{tabular}

Tabel 3. Nilai $a^{\star}$ adonan dengan bumbu berbeda pada suhu penggorengan yang berbeda

\begin{tabular}{lccrc}
\hline \multirow{2}{*}{ Adonan } & \multicolumn{4}{c}{ Suhu Penggorengan $\left({ }^{\circ} \mathrm{C}\right)$} \\
\cline { 2 - 5 } & 30 & 140 & 160 & 180 \\
\hline Bumbu 1 & $-2,59$ & $8,40 \pm 0,72^{\mathrm{b}}$ & $10,20 \pm 0,98^{\mathrm{b}}$ & $11,01 \pm 0,50^{\mathrm{a}}$ \\
Bumbu 2 & $-2,57$ & $7,65 \pm 1,38^{\mathrm{b}}$ & $8,36 \pm 0,35^{\mathrm{b}}$ & $10,89 \pm 1,29^{\mathrm{a}}$ \\
Bumbu 3 & $-2,48$ & $8,48 \pm 0,46^{\mathrm{b}}$ & $8,20 \pm 1,35^{\mathrm{b}}$ & $10,23 \pm 1,27^{\mathrm{a}}$ \\
\hline
\end{tabular}

Tabel 4. Nilai $b^{*}$ adonan dengan bumbu berbeda pada suhu penggorengan yang berbeda

\begin{tabular}{lcccc}
\hline \multirow{2}{*}{ Adonan } & \multicolumn{4}{c}{ Suhu Penggorengan $\left({ }^{\circ} \mathrm{C}\right)$} \\
\cline { 2 - 5 } & 30 & 140 & 160 & 180 \\
\hline Bumbu 1 & 20,86 & $26,79 \pm 1,09^{\mathrm{a}}$ & $23,93 \pm 1,86^{\mathrm{b}}$ & $17,49 \pm 2,34^{\mathrm{c}}$ \\
Bumbu 2 & 20,54 & $26,55 \pm 1,64^{\mathrm{a}}$ & $22,31 \pm 2,72^{\mathrm{b}}$ & $19,77 \pm 2,06^{\mathrm{C}}$ \\
Bumbu 3 & 19,43 & $27,90 \pm 1,23^{\mathrm{a}}$ & $23,78 \pm 1,53^{\mathrm{b}}$ & $19,53 \pm 2,08^{\mathrm{C}}$
\end{tabular}

Keterangan Tabel 1-4: bumbu 1, 2, dan 3 masing-masing adalah formula bumbu yang telah disesuaikan dengan kadar gula dan kadar garam dari bumbu masak komersial Masako, Royco, dan Maggi. Huruf dengan superscript yang berbeda pada baris dan kolom yang sama menunjukkan adanya perbedaan yang nyata antar perlakuan dengan tingkat kepercayaan $95 \%(\mathrm{P}<0,05)$.

Perubahan warna pada adonan merupakan hasil dari reaksi Maillard yang juga berperan dalam berkurangnya kandungan asam glutamat. Pemanasan yang berlebihan dapat menyebabkan penurunan kandungan asam amino karena terjadinya reaksi Maillard. Reaksi Maillard merupakan reaksi nonenzimatik browning antara senyawa asam amino dengan senyawa karboksil yang dapat menghasilkan perubahan warna (Echavarria et al., 2011), serta karakteristik sensori seperti aroma dan flavor pada makanan (Jaeger et al., 2010). Hal ini juga dijelaskan oleh Winarno (2008) bahwa reaksi yang terbentuk antara gula pereduksi dan kelompok asam amino dapat menyebabkan warna cokelat pada makanan yang digoreng.

Hasil kandungan asam glutamat pada adonan setelah penggorengan menunjukkan formulasi bumbu 2 mengalami penurunan kandungan asam glutamat terbesar dibandingkan dengan formulasi bumbu 1 dan 3 (Tabel 5). Berdasarkan komposisi formulasi bumbu, bumbu 2 memiliki komposisi granula Spirulina sp. tertinggi dan berbanding lurus dengan kandungan gula. Beberapa disakarida seperti sukrosa dapat terhidrolisis selama pemanasan membentuk glukosa dan fruktosa. Adanya perubahan kandungan gula dapat digunakan sebagai indikator terjadinya non-enzymatic browning (Valdramidis et al., 2010, Contreras-Calderon et al., 2009). Tingginya kandungan gula pada formulasi bumbu 2 dapat menyebabkan tingginya reaksi Maillard yang terjadi pada adonan formulasi bumbu 2, sehingga penurunan kandungan asam glutamat menjadi lebih besar. Reaksi Maillard yang terjadi antara gula pereduksi dan asam amino dapat menghancurkan asam amino tersebut.

Selain menyebabkan perubahan warna pada produk, reaksi Maillard juga berkontribusi dalam pembentukan senyawa volatil yang berkontribusi terhadap aroma (Oliveira et al., 2014). Reaksi Maillard antara gula dan senyawa amino tidak membutuhkan suhu yang sangat tinggi sehingga mudah membentuk aroma pada suhu pemasakan (Purba, 2014). Reaksi pembentukan produk senyawa volatil dimulai dengan penambahan gugus karbonil dari rantai terbuka gula pereduksi ke gugus amino utama dari asam amino yang kemudian mengalami siklisasi membentuk aldosilamin dengan substitusi nitrogen yang dapat mengalami dehidrasi dan deaminasi membentuk komponen furan. Komponen furan ini dapat bereaksi lebih lanjut dengan komponen reaktif lainnya membentuk komponen heterosiklik (Ba et al., 2012). Menurut Yu et al., (2013), reaksi Maillard yang terjadi antara gula pereduksi dan asam L-glutamat dapat membentuk senyawa pirazin yang merupakan komponen heterosiklik dari reaksi dehidrogenasi senyawa karbonil-amino yang dapat terbentuk pada suhu $100^{\circ} \mathrm{C}$ dan cenderung meningkat seiring dengan kenaikan suhu. Terjadinya penurunan kandungan asam glutamat pada semua tingkat suhu penggorengan yaitu 140 hingga $180^{\circ} \mathrm{C}$ dapat disebabkan oleh pembentukan senyawa pirazin ini.

\section{Analisis Kandungan Asam Glutamat Adonan}

Hasil analisa pendugaan kandungan asam glutamat pada bumbu dan adonan sebelum dan sesudah penggorengan pada berbagai suhu 
menunjukkan terjadinya penurunan yang signifikan pada kandungan asam glutamat sesudah mengalami penggorengan (Tabel 5). Dilain sisi, hasil uji statistik antar adonan bumbu tidak menunjukkan perbedaan yang nyata.

Tabel 5. Kandungan Asam Glutamat Adonan Sebelum dan Sesudah Penggorengan

\begin{tabular}{lcccc}
\hline \multirow{2}{*}{ Adonan } & \multicolumn{4}{c}{ Suhu Penggorengan $\left({ }^{\circ} \mathrm{C}\right)$} \\
\cline { 2 - 5 } & 30 & 140 & 160 & 180 \\
\hline Bumbu 1 & 7,354 & $6,861 \pm 0,057^{\mathrm{a}}$ & $6,075 \pm 0,175^{\mathrm{b}}$ & $3,688 \pm 0,037^{\mathrm{c}}$ \\
Bumbu 2 & 9,798 & $8,769 \pm 0,074^{\mathrm{a}}$ & $5,074 \pm 0,045^{\mathrm{b}}$ & $2,215 \pm 0,012^{\mathrm{c}}$ \\
Bumbu 3 & 8,662 & $6,975 \pm 0,101^{\mathrm{a}}$ & $5,524 \pm 0,012^{\mathrm{b}}$ & $3,752 \pm 0,064^{\mathrm{c}}$ \\
\hline
\end{tabular}

Keterangan: Huruf dengan superscript yang berbeda pada baris dan kolom yang sama menunjukkan adanya perbedaan yang nyata antar perlakuan dengan tingkat kepercayaan $95 \%$ $(P<0,05)$.

Penurunan kandungan asam glutamat ini karena adanya proses pemanasan yang berakibat pada perubahan struktur asam glutamat oleh karena reaksi dehidrasi dan secara spontan dapat membentuk asam piroglutamat yang menyebabkan penurunan asam glutamat sekitar 63\%. Dalam reaksi ini, gugus karboksilat rantai samping dari asam glutamat menjadi kehilangan gugus $\mathrm{OH}$-nya dan bergabung dengan proton dari kelompok amina membentuk air $\left(\mathrm{H}_{2} \mathrm{O}\right)$ yang menghasilkan asam piroglutamat (Lee et al., 2014). Menurut Oluwaniyi (2010) proses penggorengan pada suhu antara 175 hingga $200^{\circ} \mathrm{C}$ selama kurang dari 15 menit dapat menurunkan kandungan asam amino.

\section{Kesimpulan}

Peningkatan suhu penggorengan menyebabkan semakin rendahnya nilai $L^{*}$ dan $b^{*}$, namun dapat meningkatkan nilai a , sehingga warna adonan semakin kecoklatan. Selain itu, suhu penggorengan juga dapat menurunkan kandungan asam glutamat pada bumbu penyedap Spirulina sp.

\section{Ucapan Terima Kasih}

Penelitian ini merupakan bagian dari proyek penelitian berjudul "Produksi Penyedap nonMSG Berbasis Spirulina Menggunakan Teknologi Granula", yang didanai oleh Hibah Penelitian Strategis Nasional Institusi-DIKTI-2018/2019 no. SK 011/K6/KM/SP2H/ PENELITIAN/2018. Ketua tim Dr. Alberta Rika Pratiwi, M.Si (Universitas Katolik Soegijapranata).

\section{Daftar Pustaka}

Ba, H.V., Hwang, I., Jeong, D., Touseef, A. 2012. Principle of meat aroma flavors and future prospect. In: Akyar I, editor. Engineering technology in medicine. DOI: 10.5772/51110

Bag, S.K., Srivastav, P.P., Mishra, H.N. 2011. Optimization of process parameters for foaming of Bael (Aegle marmelos L.) fruit pulp. Food and Bioprocess Technology 4(8):1450-1458. DOI: 10.1007/s11947-009-0243-6.

Banies, D., Brown, D. 2016. Flavor enhancers: Characteristics and uses. Encyclopedia of Food and Health. 716-723. DOI: 10.1016/B978-0-12384947-2.00297-X.

Contreras-Calderón, J., Guerra-Hernández, E., GarcíaVillanova, B. 2009. Utility of some indicators related to the Maillard browning reaction during processing of infant formulas. Food Chemistry 114:1265-1270.

DOI: 10.1016/j.foodchem.2008.11.004.

De Oliveira, F.C., Coimbra, J.S., Dos R., De Oliveira, E.B., Zuniga, A.D.G., Rojas, E.E.G. 2014. Food protein-polysaccharide conjugates obtained via the Maillard reaction - A review. Critical Review in Food Science and Nutrition 13:37-41. DOI: 10.1080/10408398.2012.755669.

Dewi, E.N., Amalia, U., Mel, M. 2016. The effect of different treatments to the amino acid contents of micro algae Spirulina sp. Aquatic Procedia 7:5965. DOI: 10.1016/j.aqpro.2016.07.008.

Echavarría, A.P., Torras, C., Pagan, J., Ibarz, A. 2011. Fruit juice processing and membrane technology application. Food Engineering Review 3:136-158. DOI:10.1007/s12393-011-9042-8.

Echavarria, A.P., Pagan, J., Ibarz, A. 2016. Kinetics of color development in glucose/amino acid model systems at different temperatures. Scientia Agropecuaria 7(1):15-21. DOI: 10.17268/sci. agropecu.2016.01.02.

Fellows, P.J. 2009. Food Processing Technology $3^{\text {rd }}$ Edition Principles and Practice. Woodhead Publishing, Cambridge. DOI:10.1533/ 9781845696344.frontmatter.

Habib, M.A.B., Parvin, M., Huntington, T.C., Hasan, M.R. 2008. A review on culture, production and use of Spirulina as food for humans and feeds for domestic animals and fish. FAO Fisheries and Aquaculture Circular No. 1034, Rome.

Hartiati, A., Mulyani, S. 2015. The Effect of Maltodextrin Concentration and Drying Temperature to Antioxidant Content of Sinom Beverage Powder. Agriculture and Agricultural Science Procedia 3:231-234. DOI: 10.1016/j.aaspro.2015.01.045.

Jaeger, H., Janositz, A., Knorr, D. 2010. The Maillard reaction and its control during food processing. The potential of emerging technologies. Pathologie Biologie 58(3):207-13. DOI:10.1016/j. patbio.2009.09.016.

Jinap, S., Hajeb, P. 2010. Glutamate. Its applications in food and contribution to health. Appetite. 55:110. DOI: 10.1016/j.appet.2010.05.002.

Kuo, K.K., Acharya, R. 2012. Fundamentals of Turbulent and Multiphase Combustion. I. John Wiley \& Sons, Inc.

Kurihara, K. 2015. Umami the fifth basic taste: history of studies on receptor mechanisms and role as a food flavor. BioMed Research International. DOI: 10.1155/2015/189402.

Lee, N., Foustoukos, D.I., Sverjensky, D.A., Cody, G.D., Hazen, R.M. 2014. The effects of temperature, $\mathrm{pH}$, and redox state on the stability of glutamic acid in hydrothermal fluids. Geochimica et 
Cosmochimica Acta 135:66-86. DOI: 10.1016/j.gca.2014.02.043.

Mallikarjunan, P.K., Ngadi, M.O., Chinnan, M.S. 2010. Breaded Fried Foods. CRC Press. Taylor \& Francis Group, Boca Raton.

Moorhead, K., Capelli, B., Cysewski, G.R. 2011. Spirulina "Nature's Superfood". Cyanotech Corporation, Hawaii.

Ngadi, M., Adedeji, A.A., Kassama, L. 2008. Microstructural changes during frying of foods. Advances in Deep-Fat Frying of Foods. CRC Press. Boca Raton. 169-200.

Ninomiya, K. 2015. Science of umami taste: adaptation to gastronomic culture. Flavour 4:13. DOI: 10.1186/2044-7248-4-13.

Oluwaniyi, O.O., Dosumu, O.O., Awolola, G.V. 2010. Effect of local processing methods (boiling, frying, and roasting) on the amino acid composition of four marine fish commonly consumed in Nigeria. Food Chemistry. 123(10):1000-1006. DOI: 10.1016/j.foodchem. 2010.05.051.

Purba, Maijon. 2014. Pembentukan flavor daging unggas oleh proses pemanasan dan oksidasi $\begin{array}{ll}\text { lipida. WARTAZOA 24(3):109-118. DOI: } & \end{array}$ 10.14334/wartazoa.v24i3.1068
Sangamithra, A., Venkatachalam, S., John, S.G., Kuppuswamy, K. 2014. Foam mat drying of food materials: A review. Journal of Food Processing and Preservation. Wiley Periodicals, Inc. DOI: 10.1111/jpp.12421.

Sansone, F., Mencherini, T., Picerno, P., D'Amore, M., Aquino, R.P., Lauro, M.R. 2011. Maltodextrin/ pectin microparticles by spray drying as carrier for nutraceutical extracts. Journal of Food Engineering 105(3):468-476. DOI: 10.1016/j.jfoodeng.2011.03.004.

Valdramidis, V.P., Cullen, P.J., Tiwari, B.K., O'Donnell, C.P. 2010. Quantitative modelling approaches for ascorbic acid degradation and non-enzymatic browning of orange juice during ultrasound processing. Journal of Food Engineering 96(3):449-45. DOI: 10.1016/j.jfoodeng. 2009.08.025.

Winarno, F.G. 2008. Kimia Pangan dan Gizi. Mbrio Press, Bogor.

Yu, A.-N, Tan, Z.-W., Wang, F.-S. 2013. Mechanistic studies on the formation of pyrazines by Maillard reaction between L-ascorbic acid and L-glutamic acid. Food Science and Technology 50:64-71. DOI: 10.1016/j.lwt.2012.07.001. 